\title{
Policing the Pandemic: Tracking the Policing of Covid-19 across Canada
}

\author{
Alex Luscombe ${ }^{1}$ and Alexander McClelland ${ }^{2}$
}

Police have been centrally positioned in response to the COVID-19 pandemic. Across Canada, there has been an extraordinary scaling-up in police powers and presence in response to the virus' spread. States of emergency have been declared in every province and territory, shutting down non-essential businesses, mandating self-isolation for recent travellers, and imposing physical distancing rules. These and other virus containment rules are being enforced via provincial public health law, emergency legislation, the criminal code, and municipal by-laws, resulting in hefty fines, and a risk of potential jail time for re-offences. In certain locations, check-points have been set up, while in other areas, people are being required to identify themselves when questioned by police. In some jurisdictions, police and municipal by-law officers have been given the power to enforce public health and emergency orders. Furthermore, a myriad of "snitch lines" have been launched across Canada in an effort to bolster police intelligence via crowdsourcing. These snitch lines are encouraging people to report on those in their community breaking rules under the new pandemic normal.

The Policing the Pandemic Mapping Project was launched on 4 April, 2020 to track and visualize these massive and extraordinary expansions of police power and the unequal patterns of enforcement they are likely to produce. In doing so, we hope that we can bring to light patterns of police intervention, to help understand who is being targeted, what justifications are being used by police, and how marginalized people are being impacted. More broadly, we hope the project will inform a larger conversation about the role of policing in society, to scrutinize public health and police collaboration, and to focus attention toward the harms of criminalization. Having an understanding of these patterns in coming weeks will help inform approaches to actively resist the logic and practices of policing crisis and disease, rather than allow them to become widespread and normalized. Through the acts of identifying, reporting, and visualizing events related to the policing of COVID-19, the project offers a living repository of publicly accessible data that can be used by activists, academics, journalists, and community members to analyze, discuss, and challenge the policing of disease. We encourage all people to use the data available through this project in any way they wish.

The Policing the Pandemic Mapping Project is an exercise in counter-mapping. Following Nancy Lee Peluso[1], who

\footnotetext{
${ }^{1}$ Alex Luscombe is a PhD student at the University of Toronto. Email: alex.luscombe[at]mail.utoronto.ca

${ }^{2}$ Alexander McClelland is a postdoctoral fellow at the University of Ottawa. Email: mcclelland.alex[at]gmail.com
}

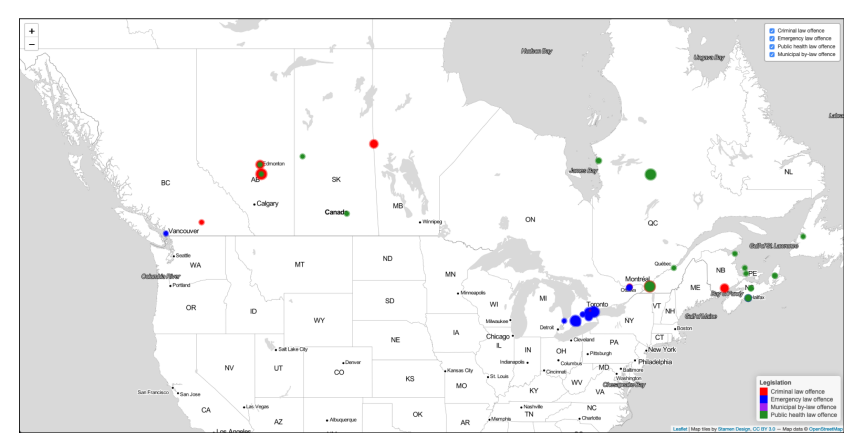

Fig. 1: Screenshot of the Policing the Pandemic Map, taken April 9, 2020, available at https://www.policingthepandemic.ca/

coined the term counter-mapping in 1995, we conceive of mapping as an "intrinsically political act" with the potential to disrupt taken-for-granted power structures and ways of governing. With Kidd[2], we further conceive of counter-mapping as a form of data activism, involving the use of data "to create knowledge about the world, denounce dominant representations, shed light on discrimination and injustice, and establish alternative social categories." Since Peluso first introduced the concept, the number of counter-mapping projects worldwide has exploded. Examples include the Anti-Eviction Mapping Project in San Francisco, the Mapping Police Violence project, the Counter-Cartographies Collective, the Detroit Geographic Expedition and Institute, and the countless uses of counter-mapping by Indigenous activists across Canada[3].

At the time of writing, there are reports of 510 people in Canada being ticketed, charged and/or arrested for COVID-19 related violations across 10 provinces. These actions are accounted for by 22 police forces and involve enforcement of numerous laws, including the federal Criminal Code, and provincial legislation, such as the Ontario Emergency Management Act or the Nova Scotia Health Protection Act, and in two Ontario jurisdictions, new municipal by-laws were passed specifically targeting COVID-19 related events. The vast majority of these police actions have taken place in the provinces of Quebec $(\mathrm{N}=323)$, Ontario ( $\mathrm{N}=93)$, and Nova Scotia $(\mathrm{N}=73)$.

While social distancing and certain other state-imposed orders aimed at the containment of COVID-19 may be effective, punishment for breaking these rules by police and other law enforcement agents is not. Policing only exacerbates and escalates crises, deterring people from seeking healthcare, while eroding the rights of dignity of targeted people[4,5]. Moreover, it is important to recognize that COVID-19 is not an equal opportunity virus, and that 


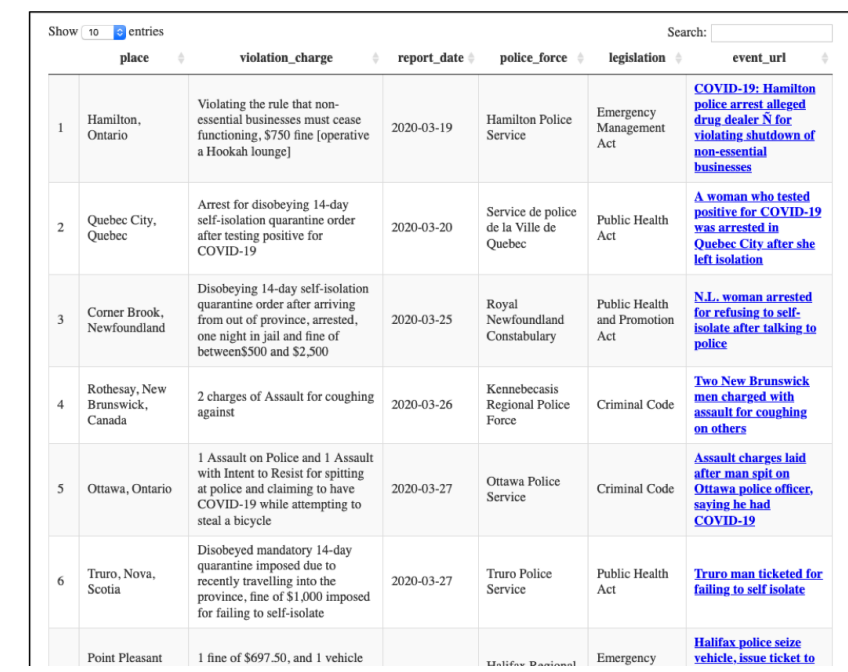

Fig. 2: Screenshot of the Policing the Pandemic Searchable Database, taken April 9, 2020, available at https://www.policingthepandemic.ca/

policing is not an equal opportunity institution. Initially, the idea circulated that COVID-19 was impacting all people equally. However, this idea has been quickly dispelled as the race and class dynamics of the pandemic become increasingly apparent. These same dynamics shape the application of laws and policing practices designed to contain illness. Based on decades of research in criminology, we know that police interventions related to COVID-19 will not impact all people equally. In Canada, our policing institution is historically rooted in the project of settler-colonisation, a project that continues today in the form of disproportionate surveillance, regulation, and incapacitation of Indigenous people[6,7]. Black and other racialized groups in Canada have long been subject to disproportionate harm from law enforcement in Canada, beginning with the numerous drug wars of the early 20th century $[8,9]$. The long history of over-policing in poor and working-class communities in Canada (whom are often also racialized) is similarly well documented[10,11]. The fact that this legacy of racialized and class-based targeting by police in Canada is still with us $[12,13]$ is precisely why we should be concerned about the extraordinary boosts to police power and enforcement we are seeing around the spread of COVID-19.

We have said it before and will continue to say it until this message is clearly heard: We cannot police our way out of this pandemic.

\section{REFERENCES}

[1] N. L. Peluso, "Whose woods are these? counter-mapping forest territories in kalimantan, indonesia," Antipode, vol. 27, no. 4, pp. 383-406, 1995.

[2] D. Kidd, "Extra-activism: counter-mapping and data justice," Information, Communication \& Society, vol. 22, no. 7, pp. 954-970, 2019.

[3] G. L. Eades, Maps and memes: Redrawing culture, place, and identity in Indigenous communities, vol. 76. McGill-Queen's Press-MQUP, 2015.
[4] N. Bulled and E. C. Green, "Making voluntary medical male circumcision a viable hiv prevention strategy in high-prevalence countries by engaging the traditional sector," Critical public health, vol. 26, no. 3, pp. 258-268, 2016.

[5] B. D. Adam, R. Elliott, P. Corriveau, and K. English, "Impacts of criminalization on the everyday lives of people living with hiv in canada," Sexuality Research and Social Policy, vol. 11, no. 1, pp. 39-49, 2014.

[6] C. Proulx, "Colonizing surveillance: Canada constructs an indigenous terror threat," Anthropologica, pp. 83-100, 2014.

[7] J. Monaghan, "Mounties in the frontier: Circulations, anxieties, and myths of settler colonial policing in canada," Journal of Canadian Studies, vol. 47, no. 1, pp. 122-148, 2013.

[8] A. Khenti, "The canadian war on drugs: Structural violence and unequal treatment of black canadians," International Journal of Drug Policy, vol. 25, no. 2, pp. 190-195, 2014.

[9] A. Owusu-Bempah, "Race and policing in historical context: Dehumanization and the policing of black people in the 21st century," Theoretical Criminology, vol. 21, no. 1, pp. 23-34, 2017.

[10] M.-È. Sylvestre, "Policing the homeless in montreal: is this really what the population wants?," Policing \& Society, vol. 20, no. 4, pp. 432-458, 2010

[11] T. Gordon, "The return of vagrancy law and the politics of poverty in canada," Canadian Review of Social Policy, no. 54, p. 34, 2004.

[12] M. Tulloch, "Report of the independent street checks review," 2018.

[13] R. Maynard, Policing Black lives: State violence in Canada from slavery to the present. Fernwood Publishing, 2017. 